\title{
Obituary
}

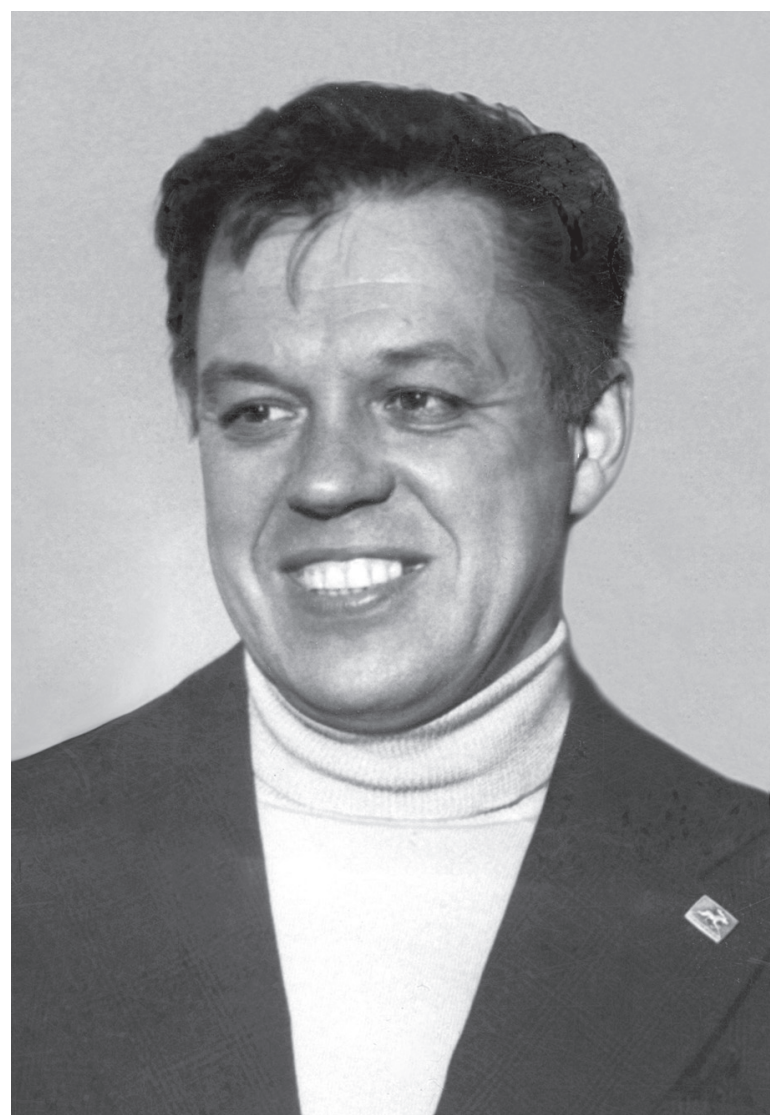

\section{Igor Mikhailovich Fokin (1933-2017)}

After two decades of severe struggle with serious disease and disability Dr. Igor Mikhailovich Fokin, age 84, passed away July 25, 2017, in Saint Petersburg, Russia. He was a prominent specialist in morphology, ecology and locomotion of small mammals, rodents and jerboas in particular.

Igor Fokin was born on June 2, 1933, in Leningrad. His father Mikhail Vasil'evich Bogdanov (1888 year of birth) was arrested and executed by shooting in 1937. His mother Klavdia Andreevna Fokina (1899-1976) has been working as a work-force in the Northern shipyard until the Russian revolution, after that she became an accountant in several institutions in Leningrad.

Igor lost his father at a young age. He spent his childhood with his mother and his grandfather's family. His grandfather, Andrei Fokievich Fokin, was working in Kirovsky factory in Leningrad as a specialist at that time. At the beginning of The Great Patriotic War Igor was only seven years old. He was evacuated in Kirov Region along with his aunt, his mother's sister, and went to school in 1941. After lifting of the Blockade in 1944 he returned to Leningrad and later graduated from a secondary school in Leningrad. His favourite classes were natural history science and geography. He took extra lessons to learn more about these subjects and beef up his knowledge beyond the borders of the school curriculum.

After graduation in 1951, Igor was accepted in the Leningrad State University (now - Saint Petersburg State University) on the Biological Faculty and graduated in 1956. During his education in the Department of Vertebrate Zoology, he studied the ecology of rodents under the supervision of Dr. Oleg Petrov. During 19541956 I.M. Fokin studied the forestry importance of mouse-like rodents on experimental seed plots in the forest-steppe zone in wildlife sanctuary "Woods on Vorskla" in the Belgorod Region. He used these studies to prepare his Master's Thesis. He finished writing his thesis in 1956. These materials were published later (Petrov \& Fokin, 1960).

After graduation, Igor Fokin got a permanent position as a zoologist in the Turkmenia Republic of USSR (now - Turkmenistan). He spent three years in Tashauz (now Daşoguz) Department of the Turkmenian AntiPlague Service. During the Soviet time, the southern 
borders of USSR were considered as "Eldorado" for zoologists due to the richness and uniqueness of local faunas. Igor Fokin worked in the Kara-Kum Desert in the western part of Tashauz Region for studies of rodent distribution and pest control. In the sands of KaraKum he found not only amazing mammals but also true love. Anna Airapetyants, his university classmate, captured his heart. He stayed with Anna all his life.

In Kara-Kum, I.M. Fokin fell in love with the desert and its inhabitants. He was especially interested in jerboas. He started gathering data on their ecology and means of adaptation to life in the desert. In 1958 his first scientific paper was published, devoted to Bobrinski's jerboa Allactodipus bobrinskii in Kara-Kum Desert (Airapetyants \& Fokin, 1958). Airapetyants and Fokin also found new species of jerboa in Kara-Kum, Siberian jerboa Allactaga sibirica, that was unknown to Turkmenistan fauna before (Airapetyants \& Fokin, 1961). Scientific articles about Aral thick-tailed jerboa, about ecology and distribution of Bobrinski's jerboa and combtoed jerboa's food followed (Fokin, 1963a, 1969a; Airapetyants et al., 1978). Along with studies of desert mammals' biology I.M. Fokin explored their unique locomotion. He was dreaming of studying jerboas' locomotion under the guidance of the famous scientist Prof. Boris Vinogradov in the Zoological Institute, USSR Academy of Sciences. Unfortunately, Prof. Vinogradov passed away in 1958, while Fokin was still working in Turkmenistan.

Igor and Anna came back to Leningrad in 1959. In December 1959 Igor became a $\mathrm{PhD}$ student in the Zoological Institute, USSR Academy of Sciences. His supervisor in Zoological Institute, Dr. Igor Gromov, supported his study of the functional morphology of jerboas of Dipodidae family. The main goal of I.M. Fokin studies was uncovering the ways of ecological and morphologic peculiarities of Dipodidae family and developing morpho-biological specifications of the family's taxa using this knowledge. In his work, he used methods of comparative ecology, comparative morphology and functional anatomy. Moreover, he used rapid photographic shooting and filming and also X-ray photography. Dr. Evgenia A. Klebanova, Dr. Anatoly S. Sokolov and Dr. Petr P. Gambaryan were his main mentors in animal morphology, and under their guidance he studied methodology of morphological researches. At that time he published papers about peculiarities of running in jerboas, methods of locomotion researches and morphology of muscles of jerboas (Fokin, 1963b, 1966, 1969b). Research of comparative anatomy of hind limb muscles of genera Sicista and Salpingotus helped to position Cardiocraniinae subfamily in Dipodidae system (Fokin, 1971b). He successfully defended his PhD thesis "Locomotion and transformation of movement apparatus of jerboa (Dipodidae) in the process of their specialization" on 14 October 1971 in the Leningrad State University. In 1978 materials of this thesis were published in the monograph "Locomotion and Morphology of Movement Apparatus of Jerboas" (Fokin, 1978b).
For a long time, from 1963 up to 1980, Igor Fokin was working in the Laboratory of the ecology of terrestrial vertebrates in the Biological Scientific Institute of the Leningrad State University. He started his work in this Institute as a research assistant in 1963. Since 1964 he got a permanent position as a junior research scientist in the Laboratory of the ecology of terrestrial vertebrates.

During his research of biomechanics and functional morphology of mammals' movement apparatus, Fokin developed new methods of instrumental analysis of mammalian locomotion, including rapid photographic shooting and filming and individual marking of animals. These methods helped him to gather valuable data to prove a theory about the origins of new locomotion forms in the evolution of mammals. Analysis of highlighted opening phases of forward movement in reptiles and rodents let I.M. Fokin form a theory about origins of speed bipedalism in tetrapods.

I.M. Fokin was a natural morphologist. His university professors took notice of it when he was still a student. His morphological preparations were the best in the class. He was an incredibly rational person and was always in search of new methods and techniques. That is why his research is very important for jerboa family studies as well as the comparative and ecological morphology of mammals. His papers on morphofunctional features of the muscular apparatus of head in the jerboas are especially noteworthy (Gambaryan \& Fokin, 1976; Gambaryan et al., 1980). Authors analysed muscles of masticatory apparatus and facial muscles of all Dipodidae genera and came to a conclusion that the main ways of face muscles development, controlling movements of ears, eyes, nose and lips were going in different directions from birch mice and elephant shrews, even with similar functions.

In 1978 his monography "Jerboas" was published by the Leningrad University Press in series "Life of our birds and mammals" (Fokin, 1978a). This monography explored biology, distribution and behaviour of jerboa superfamily. One chapter in this book is dedicated to describing modes of locomotions in jerboas and morphological devices for fast running and digging.

I.M. Fokin actively took part in several academic conferences, congresses and workshops. On the First Congress of the All-Union Theriological Society (Moscow, 1974) he presented a paper on the evolution of modes of locomotion and ways of transformation of movement apparatus of Dipodidae (Fokin, 1974); on All-Union Conference on ecology of carnivores he shared materials on peculiarities of movements of mustelids on snow (Fokin, 1979); on Sixth USSR Conference on Rodents he made a report on peculiarities of muscle system of pygmy jerboa (Fokin, 1983) and also postnatal ontogenesis of edible dormouse and thicktailed jerboa (Airapetyants \& Fokin, 1983a, b); on International Conference "Biodiversity of European North" he brought attention to the actual state and environmental constraints of biodiversity of mammals 


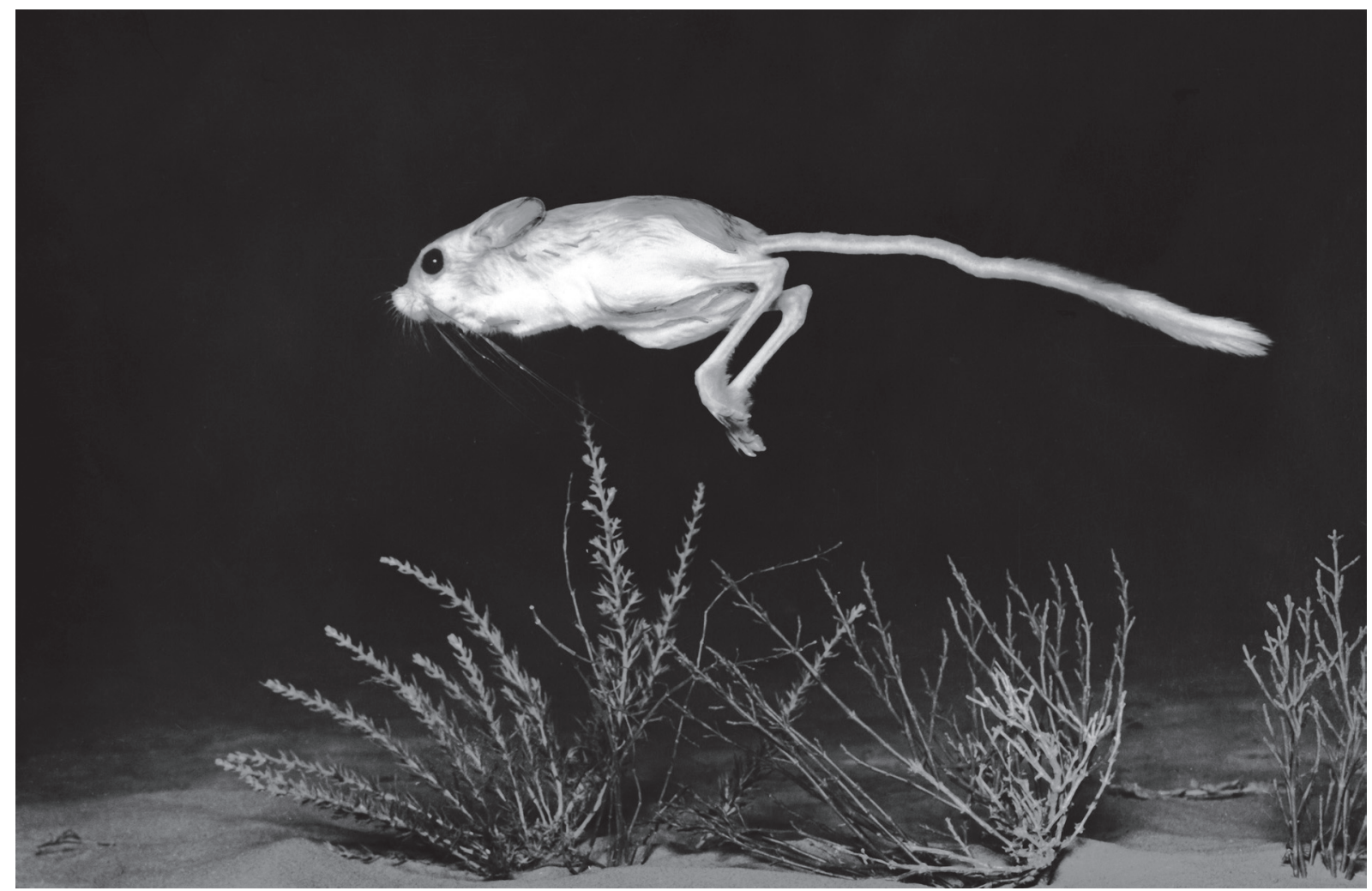

Study of locomotion in mammals was the main scientific passion of Dr. I Fokin. Jumping comb-toed jerboa Paradipus ctenodactylus, Kara-Kum Desert. Photographed by I.M. Fokin.

community of Leningrad Region (Fokin \& Airapetyants, 2001). Igor Fokin was an active member of AllUnion Theriological Society of the USSR Academy of Science. On the Second Congress of the All-Union Theriological Society (Moscow, 1978) he was elected as a member of main board in All-Union Theriological Society.

Aside from scientific research I.M. Fokin took a keen interest in educational work - led summer internship for the Leningrad State University students, taught a course on anatomy of laboratory animals for the students of the Department of Vertebrate Zoology, was a supervisor for students' term papers and graduation theses.

During a long time Igor Fokin continued the scientific researches in Turkmenistan. In 1975 together with Anna Airapetyants he established the scientific-educational zoological station "Shakh-Senem" in the KaraKum Desert. Many students of the Leningrad State University were spending their summer practice there, gathering materials for graduation theses and $\mathrm{PhD}$ theses. This station was also loved by scientists from the Leningrad State University and the Zoological Institute who were studying biology, morphology and adaptation of mammals in the desert. Zoological station "Shakh-Senem" existed up to the end of the Soviet Union era in 1991. Another zoological station "Shul'gino" was established for the same purposes in Boksitogorsk
District on the southeast of the Leningrad Region. "Shul'gino" Station was opened in 1965 and still exists nowadays.

On June 2nd, 1980 Igor Fokin was elected as a head of the Laboratory of Mammalogy in Zoological Institute USSR Academy of Sciences, taking over from Prof. Igor Gromov, who was in charge of the laboratory during 1974-1980. Igor Fokin was a head of the Laboratory of Mammalogy up to 1997. During this time the Laboratory of Mammalogy became one of the largest and most important departments in the Zoological Institute. Fokin was a supervisor for $\mathrm{PhD}$ theses of Olga Zherebtsova, Alexei Abramov and Kirill Tretyakov (all of them are working as researchers in the Zoological Institute now).

Despite the fact that his main duties were connected with the laboratory, he was also involved in the museum exhibitions and has been to Japan, Finland, USA, and Sweden with different museum exhibitions from the Zoological Institute.

Igor Fokin was an outstanding natural scientist. He spent his last years in nature, researching different species of vertebrates. Aside from desert jerboas his favourite animals were dormice (Gliridae) and flying squirrels (Pteromys). I.M. Fokin gave all his time and energy to the research of his home region's nature. He was always working on conservation of mammals in the North-West of Russia, taking part in "Lenkompriroda" 
(i.e. Leningrad State Committee of Nature Conservation) activities. He orchestrated publishing of "Nature of Leningrad Region" monograph series, the first book in this series being "Mammals" (Airapetyants, Strelkov $\&$ Fokin, 1987). Igor Fokin was an expert of commission on rodents in USSR Red Data Book and Leningrad Region Red Data Book, and also a member of Commission on the compilation of "Inventory of USSR fauna".

I.M. Fokin did not stop his scientific researches even after a severe blood stroke in spring 1999. He used to come to "Shul'gino" Station every summer until his demise, spending all his time there on researching ecology of small mammals in the woods near the station.

I.M. Fokin was one of the renowned experts in the ecological morphology of mammals. His researches were defined by a combination of morphological method with instrumental analysis of life-sustaining activities of animals. In-depth study of modes and functions of locomotory apparatus in several groups of mammals let I.M. Fokin see a problem of the evolutionary evolvement of different forms of forward movements in mammals from a new point of view. He developed a new methodological approach and successfully applied it to the analysis of ways of adaptive evolution in a Dipodidae superfamily. He published three monographs and over forty scientific papers based on results of his researches.

He will always be dearly remembered as a bright, interesting person, who is passionate about his work, a brilliant planner and talented researcher.

\section{Elena P. Tikhonova, Alexei V. Abramov \& Alexei N. Tikhonov}

\section{List of publications by Dr. Igor Fokin}

Airapetyants A.E. \& Fokin I.M. 1958. [Bobrinski's jerboa in Kara-Kum Desert] // Priroda. No.8. P.119 [in Russian].

Petrov O.V. \& Fokin I.M. 1960. [Distribution and number of mouse-like rodents on seed stands in forest-steppe woods] // Vestnik Leningradskogo Universiteta. Seriya Biologicheskaya. No.315. P.69-81 [in Russian].

Airapetyants A.E. \& Fokin I.M. 1961. [New species in fauna of rodents in Turkmenia - Siberian jerboa (Allactaga sibirica Forst.)] // Vestnik Leningradskogo Universiteta. Seriya Biologicheskaya. No.21. P.21-22 [in Russian].

Fokin I.M. 1963a. [Jerboa and argali on Ustyurt Plateau] // Priroda. No.3. P.67-69 [in Russian].

Fokin I.M. 1963b. [Peculiarities of running of jerboa] // Byulleten' Moskovskogo Obshchestva Ispytatelei Prirody. Otdel Biologicheskii. Vol.68. No.5. P.22-28 [in Russian].

Fokin I.M. 1966. [About methods of study peculiarities of locomotion of rodents] // [Mechanics of Biological Processes]. Leningrad. P.62-63 [in Russian].

Fokin I.M. 1969a. [To the ecology and distribution of Bobrinski's jerboa in Kara-Kum Desert] // [Questions of Ecology and Biocenology]. No.9. P.124-135 [in Russian].

Fokin I.M. 1969b. [Locomotion and morphology of muscles of movement apparatus of Dipodidae] // [Mechanics of Biological Processes]. Leningrad. P.67-68 [in Russian].
Novikov G.A., Airapetyants A.E., Pukinsky Yu.B., Timofeeva E.K. \& Fokin I.M. 1969. [Brown bear in Leningrad Region] // Byulleten' Moskovskogo Obshchestva Ispytatelei Prirody. Otdel Biologicheskii. Vol.74, No.3. P.102117 [in Russian].

Novikov G.A., Airapetjants A.E., Pukinsky Yu.B., Timofeeva E.K. \& Fokin I.M. 1969. [Some peculiarities of the population of brown bears in the Leningrad Region] // Zoologicheskii Zhurnal. Vol.48. No.6. P.885-901 [in Russian].

Fokin I.M. 1971a. [Locomotion and transformation of movement apparatus of jerboa (Dipodidae) in the process of their specialization]. Avtoreferat dissertatsii kandidata biologicheskikh nauk [Abstract of PhD Dissertation in Zoology]. Leningrad: Leningrad State University. 20 p. [In Russian]

Fokin I.M. 1971b. [Comparative anatomy of hind limb muscles of the genus Sicista and Salpingotus (to place the Cardiocraniinae subfamily in Dipodidae system] // Trudy Zoologicheskogo Instituta AN SSSR. Vol.48. P.181197 [in Russian].

Fokin I.M. 1974. [Evolution of modes of locomotion and ways of the transformation of movement apparatus of Dipodidae (Rodentia)] // The First Congress of the AllUnion Theriological Society. Abstracts of Papers. Vol.2. Moscow. P.291-292 [in Russian].

Gambaryan P.P. \& Fokin I.M. 1976. [Convergent development of particular muscles of facial region of the jerboas (Rodentia, Mammalia)] // Doklady Akademii Nauk SSSR. Vol.231. No.3. P.733-735 [in Russian].

Fokin I.M. 1978a. [Jerboas]. Leningrad: Leningrad University Press. 183 p. [in Russian].

Fokin I.M. 1978b. [Locomotion and Morphology of Movement Apparatus of Jerboas]. Leningrad: Nauka. 119 p. [In Russian]

Airapetijanz A.E., Nikolskaja N.S. \& Fokin I.M. 1978. [The feeding of Paradipus ctenodactylus Vinogradov, 1930 in north Karakum desert] // Trudy Zoologicheskogo Instituta AN SSSR. Vol.79. P.72-78 [in Russian].

Fokin I.M. 1979. [Peculiarities of movements of mustelids on snow] // [Ecological Basics of Preservation and Rational Usage of Carnivores]. Abstracts of Papers. Moscow. P.350-351 [in Russian].

Gambaryan P.P., Potapova E.G. \& Fokin I.M. 1980. [Morphofunctional features of the muscular apparatus of head in the jerboas (to the justification of the natural system of Dipodoidea, Rodentia, Mammalia)] // Trudy Zoologicheskogo Instituta AN SSSR. Vol.91. P.3-51 [in Russian].

Fokin I.M. 1981a. [About origins of speed bipedalism of reptiles] // [Questions of Herpetology]. Leningrad. P.137138 [in Russian].

Fokin I.M. 1981b. [Peculiarities of locomotion of desert rodents] // [Ecology and Medical Importance of Gerbils of USSR fauna]. Abstracts of Papers. Moscow. P.319322 [in Russian].

Airapetyants A.E., Nikol'skaya N.S. \& Fokin I.M. 1983. [Burrowing of psammophile jerboas (Rodentia, Dipodidae)] // Trudy Zoologicheskogo Instituta AN SSSR. Vol.119. P.89-99 [in Russian]. 
Airapetyants A.E. \& Fokin I.M. 1983a. [About postnatal ontogenesis of edible dormouse] // Sixth USSR Conference on Rodents. Abstracts of Papers. Leningrad: Nauka. P.284-286 [in Russian].

Airapetyants A.E. \& Fokin I.M. 1983b. [Peculiarities of postnatal development of thick-tailed jerboa] // Sixth USSR Conference on Rodents. Abstracts of Papers. Leningrad: Nauka. P.286-288 [in Russian].

Fokin I.M. 1983. [Peculiarities of the muscular system of pygmy jerboa] // Sixth USSR Conference on Rodents. Abstracts of Papers. Leningrad: Nauka. P.202-204 [in Russian].

Airapetyants A.E. \& Fokin I.M. 1986. [Peculiarities of postnatal ontogenesis of dormice (Gliridae, Rodentia)] // Fourth Congress of the All-Union Theriological Society. Abstracts of Papers. Moscow. Vol.2. P.4-5 [in Russian].

Airapetyants A.E., Strelkov P.P. \& Fokin I.M. 1987. [Nature of Leningrad Region. Mammals]. Leningrad: Lenizdat. 144 p. [In Russian]

Grafodatsky A.S. \& Fokin I.M. 1993. [Comparative cytogenetics of Gliridae (Rodentia)] // Zoologicheskii Zhurnal. Vol.72. No.11. P.104-113 [in Russian].

Airapetyants A.E. \& Fokin I.M. 1997. [About garden dormouse Eliomys quercinus in Leningrad Region] // [Rare Species of Mammals in Russia and Cross-border Regions]. International Conference, Abstracts of Papers. Moscow. P.5 [in Russian].

Airapetjanz A. \& Fokin I. 1998. Woodlands in the Leningrad region and local mammalian fauna // Baltic Bulletin. No.2. P.39-41.

Hokkanen H. \& Fokin I. 1998. Pteromys volans // Red Data Book of East Fennoscandia. Helsinki: Ministry of the Environment Institute. P.203-204.

Airapetyants A.E. \& Fokin I.M. 2001. [Reduction of number of European flying squirrel Pteromys volans L.) and garden dormouse (Eliomys quercinus L.) under the influence of anthropogenic of natural landscapes of Leningrad Region] // Biodiversity of the European North (theoretical basis of the study, socio-legal aspects of the use and conservation): Abstracts, presented to the International Conference (September 3-7, 2001, Petrozavodsk). Petrozavodsk. P.5-6 [in Russian].

Fokin I.M. \& Airapetyants A.E. 2001. [Actual state and environmental constraints of biodiversity of mammals community of Leningrad Region] // Biodiversity of the European North (the theoretical basis of the study, sociolegal aspects of the use and conservation): Abstracts, presented to the International Conference (September 37, 2001, Petrozavodsk). Petrozavodsk. P.181-182 [in Russian].

Ajrapetjanz A.E. \& Fokin I.M. 2002. Least (Pygmy) Shrew Sorex minutissimus Zimm. // [Red Data Book of Nature of the Leningrad Region]. Vol.3. Animals. Sankt-Peterburg: Mir i Sem'ya. P.433-434.

Ajrapetjanz A.E. \& Fokin I.M. 2002. Flying Squirrel Pteromys volans (L.) // [Red Data Book of Nature of the Leningrad Region]. Vol.3. Animals. Sankt-Peterburg: Mir i Sem'ya. P.440-441.

Ajrapetjanz A.E. \& Fokin I.M. 2002. Garden Dormouse Eliomys quercinus (L.) // [Red Data Book of Nature of the Leningrad Region]. Vol.3. Animals. Sankt-Peterburg: Mir i Sem'ya. P.441-442.

Ajrapetjanz A.E. \& Fokin I.M. 2002. Root Vole Microtus oeconomus (Pall.) // [Red Data Book of Nature of the Leningrad Region]. Vol.3. Animals. Sankt-Peterburg: Mir i Sem'ya. P.443-444.

Ajrapetjanz A.E. \& Fokin I.M. 2002. Pine Vole Microtus (Terricola) subterraneus Sel.-Long. // [Red Data Book of Nature of the Leningrad Region]. Vol.3. Animals. Sankt-Peterburg: Mir i Sem'ya. P.444-445.

Ajrapetjanz A.E. \& Fokin I.M. 2002. European Mink Mustela lutreola (L.) // [Red Data Book of Nature of the Leningrad Region]. Vol.3. Animals. Sankt-Peterburg: Mir i Sem'ya. P.446-447.

Ajrapetjanz A.E. \& Fokin I.M. 2002. Wolverine Gulo gulo (L.) // [Red Data Book of Nature of the Leningrad Region]. Vol.3. Animals. Sankt-Peterburg: Mir i Sem'ya. P.448-449.

Ajrapetjanz A.E. \& Fokin I.M. 2002. 295. Otter Lutra lutra (L.) // [Red Data Book of Nature of the Leningrad Region]. Vol.3. Animals. Sankt-Peterburg: Mir i Sem'ya. P.449-451.

Ajrapetjanz A.E., Verevkin M.V., Sagitov R.A. \& Fokin I.M. 2002. Ringed Seal Phoca hispida Schreb., Baltic Ringed Seal P. h. botnica Gmelin // [Red Data Book of Nature of the Leningrad Region]. Vol.3. Animals. SanktPeterburg: Mir i Sem'ya. P.451-452.

Ajrapetjanz A.E., Verevkin M.V. \& Fokin I.M. 2002. Ringed Seal Phoca hispida Schreb., Ladoga Ringed Seal P. $h$. ladogensis Nordquisi // [Red Data Book of Nature of the Leningrad Region]. Vol.3. Animals. Sankt-Peterburg: Mir i Sem'ya. P.453-454.

Ajrapetjanz A.E., Verevkin M.V., Sagitov R.A. \& Fokin I.M. 2002. Grey seals Halichoerus grypus (F.), Baltic Grey Seal H. g. macrorhynchus // [Red Data Book of Nature of the Leningrad Region]. Vol.3. Animals. SanktPeterburg: Mir i Sem'ya. P.454-455.

Ajrapetjanz A.E. \& Fokin I.M. 2002. European Roe Deer Capreolus capreolus (L.) // [Red Data Book of Nature of the Leningrad Region]. Vol.3. Animals. Sankt-Peterburg: Mir i Sem'ya. P.455-456.

Airapetyants A.E. \& Fokin I.M. 2003. Biology of European flying squirrel Pteromys volans L. (Rodentia: Pteromyidae) in the North-West of Russia // Russian Journal of Theriology. Vol.2. No.2. P.105-113.

Airapetyants A.E. \& Fokin I.M. 2004. [Biology of European flying squirrel (Pteromys volans) in the North-West of Russia] // [Proceedings of Biological Scientific Research Institute of Saint Petersburg State University]. No.48. P.15-34 [in Russian].

Fokin I.M. \& Airapetyants A.E. 2004. [Introduced mammals in Russia: ecological and economic effect] // [Biological invasions in aquatic and terrestrial ecosystems]. Moscow: KMK Scientific Press. P.320-240 [in Russian].

Fokin I.M. \& Ayrapetianz A.E. 2005. [Game mammals species resources in the North-West of European Russia] // [Basic Grounds of Biological Resources Management]. Moscow. P.229-238 [in Russian with English summary]. 